\title{
Optimising cardioprotection during myocardial ischaemia: targeting potential intracellular pathways with glucagon-like peptide-1
}

\author{
Sophie J Clarke, Liam M McCormick and David P Dutka*
}

\begin{abstract}
Coronary heart disease and type-2 diabetes are both major global health burdens associated with an increased risk of myocardial infarction (MI). Following MI, ischaemia-reperfusion injury (IRI) remains a significant contributor to myocardial injury at the cellular level. Research has focussed on identifying a strategy or intervention to minimise IRI to optimise reperfusion therapy, with the aim of delivering a superior clinical outcome. The incretin hormone glucagon-like peptide-1, already an established basis for the treatment of type-2 diabetes, also has the potential to protect against IRI. We explain the physiology and cellular processes involved in IRI, and the intracellular pathways activated by GLP-1, which could intercept IRI and deliver cardioprotection. The review also examines the current preclinical and clinical evidence for GLP-1 in cardioprotection and future directions for research as we look for an effective adjunctive treatment to minimise IRI.
\end{abstract}

Keywords: GLP-1, Glucagon-like peptide-1, Incretin, Ischaemia, Ischaemia-reperfusion, Cardioprotection, Myocardial metabolism, Diabetes, Percutaneous coronary intervention, Myocardial infarction

\section{Background}

Coronary heart disease is the leading global cause of death in the developed world, with myocardial infarction (MI) being associated with significant morbidity and mortality. Type-2 diabetes is another major global health burden, with prevalence continuing to increase. Compared with the general population, patients with type-2 diabetes have a significantly increased risk of MI as well as a higher risk of mortality or developing heart failure within 30 days after an event [1,2].

Myocardial injury following MI can be either lethal or sub-lethal, depending on the duration and severity of ischaemia endured. Sub-lethal ischaemia is often associated with reversible contractile dysfunction, although this may be prolonged due to stunning and hibernation. Stunning is transient, while hibernation is a more prolonged reduction in myocardial performance following ischaemia-reperfusion. The success of timely primary percutaneous coronary intervention (PCI) in those presenting with an acute MI has seen mortality rates fall to

\footnotetext{
* Correspondence: dpd24@medschl.cam.ac.uk

Department of Cardiovascular Medicine, University of Cambridge, Addenbrooke's Hospital, Cambridge, UK
}

$6 \%$ [3], as the length of ischaemia is directly related to the final extent of infarction. The process of reperfusion itself also contributes, rapidly changing the intracellular physiological environment including activation of pathways that may induce lethal myocardial injury. Such ischaemia-reperfusion injury (IRI), with resultant apoptosis, necrosis and post-ischaemic dysfunction remains a key determinant of the final extent of infarction, degree of myocardial salvage and the overall associated morbidity and mortality of MI (illustrated in Figure 1a) $[4,5]$.

There has been considerable interest recently in whether the IRI pathway offers a potential target to protect the myocardium beyond what can be achieved by the physical means of PCI (including thrombectomy). Important therapeutic targets include promoting myocyte glucose metabolism to enable relatively more ATP generation when oxygen supply is constrained, and activation of prosurvival kinase pathways to protect the mitochondria. Pro-survival kinase pathways are known to be activated by ischaemic conditioning; a mechanical intervention employing a series of brief, sub-lethal periods of ischaemia to protect the heart against a subsequent lethal ischaemic insult [6]. Pre-, per- and post-conditioning are performed before, 


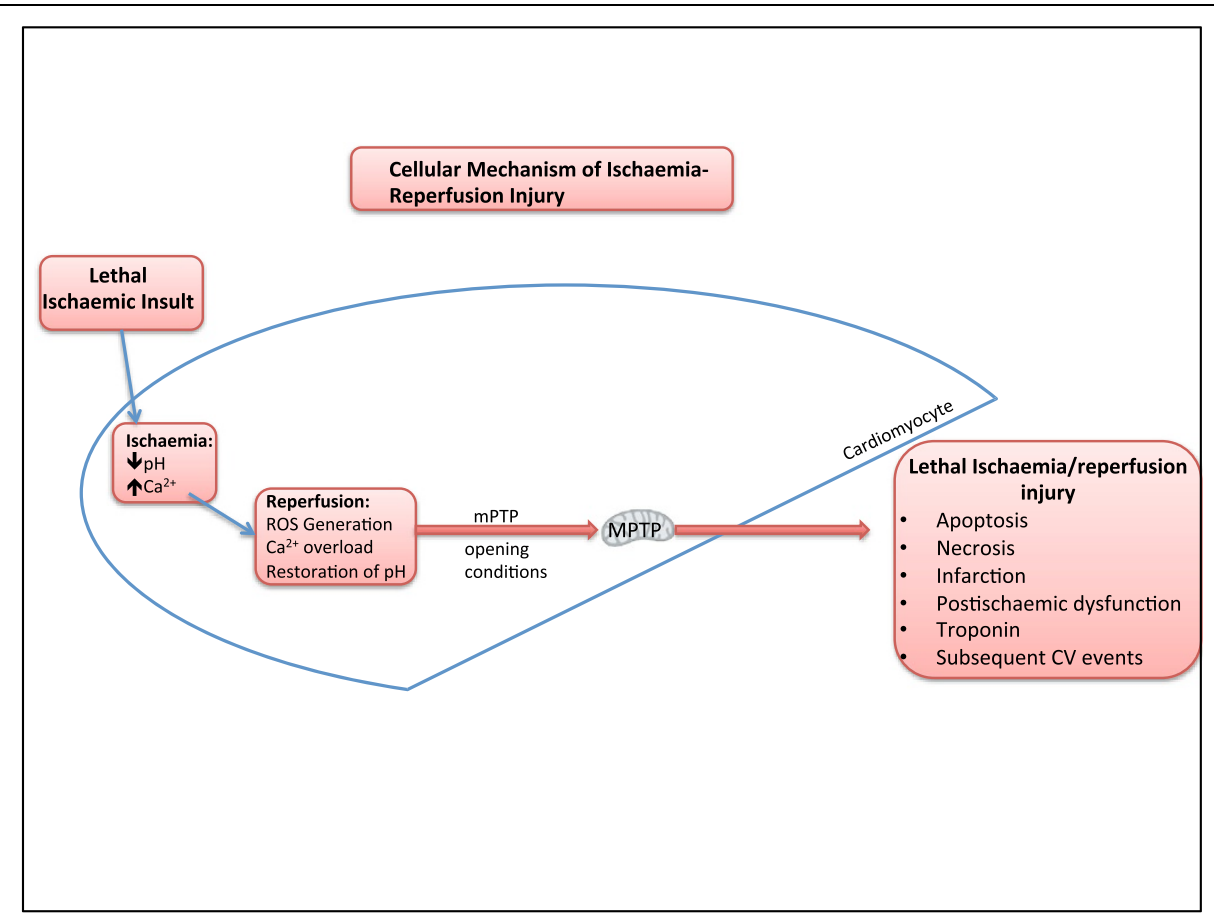

$\mathbf{a}$

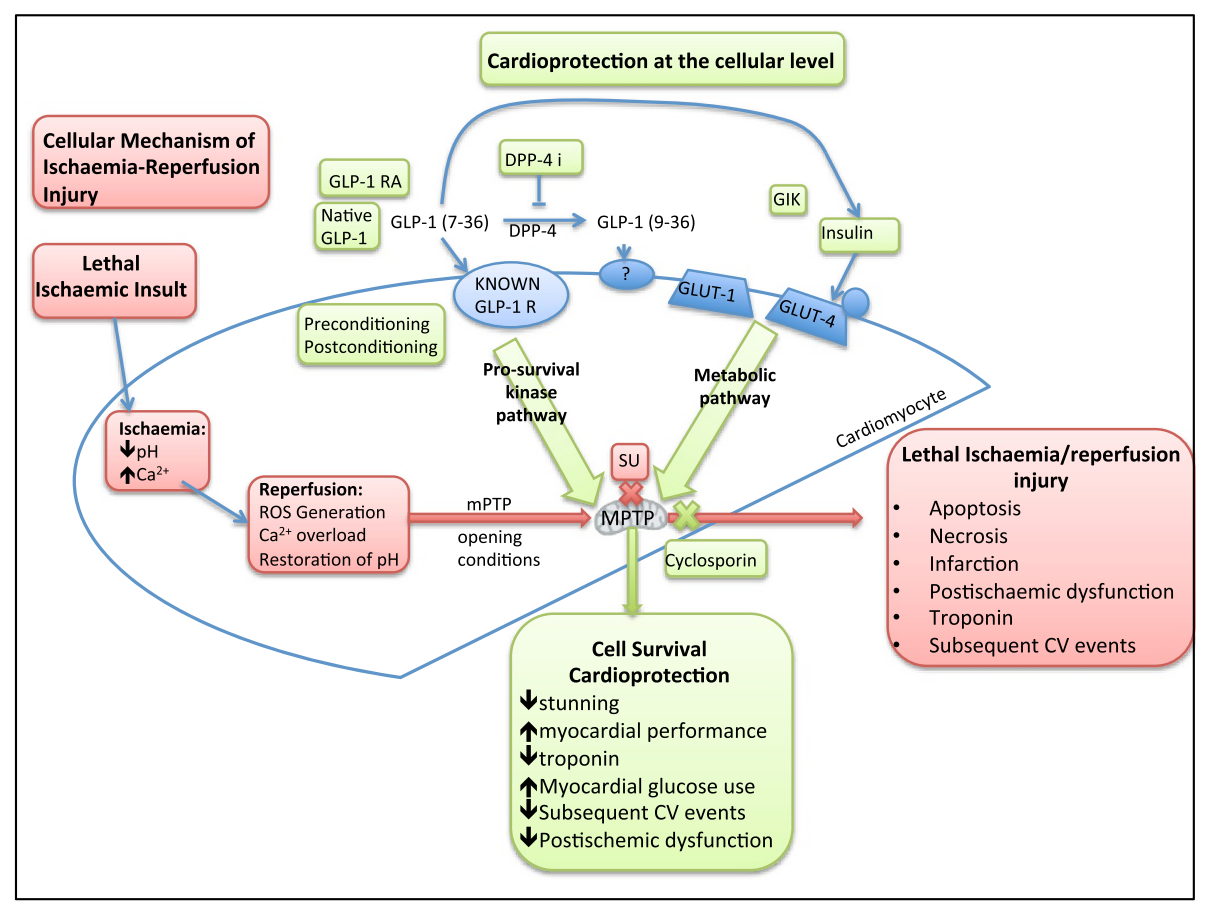

b

Figure 1 Possible mechanisms of protection against IRI by GLP-1. (a) Cellular mechanism of lethal ischaemic injury. (b) The links between the known intracellular pathways involved in IRI and the two distinct cardioprotective pathways capable of interrupting this: The pro-survival kinase pathway, and the metabolic pathway. MPTP is the intersection between the two pathways. The possible second GLP-1 receptor remains a hypothesis. Also shown are known modulators of the pathways and clinical measures of cardioprotection [9,23,24,47]. 
during or after reperfusion respectively. The incretin hormone glucagon-like peptide-1 (GLP-1) stimulates glucosedependent insulin release, and may also modulate the cellular processes and conditioning pathways during ischaemia-reperfusion, possibly providing cardioprotection. In this review, the evidence supporting the beneficial effects of GLP-1 on myocardial function during ischaemiareperfusion will be discussed in the context of recent preclinical and clinical data.

\section{Myocardial metabolism in ischaemia-reperfusion}

The primary function of the heart is to maintain the circulation. Cardiomyocytes have very limited capacity for energy storage, but a considerable demand requiring an almost continuous local synthesis of ATP [7]. To facilitate this mitochondria are particularly abundant in cardiomyocytes occupying over $30 \%$ of the normal cell volume [8]. This enables the heart to meet ATP demand with energy flowing through a series of connected, moiety-conserved cycles. However, this necessitates a continuous rich supply of oxygen and substrates to maintain optimum contractile performance [7].

Cardiomyocytes have been described as the ultimate omnivore with cells having the ability to rapidly change the metabolic substrates for ATP production depending on their availability and the energy demands of the heart. Glucose and free fatty acids (FFA) are the two most important substrates, with each inhibiting the metabolism of the other, such that the most prevalent substrate dictates cellular metabolism $[7,9]$. Under fasting conditions, FFAs predominate, but this is less oxygen efficient than glucose metabolism [9]. Post-prandially, increase in circulating concentrations of glucose and insulin enhance glucose uptake into the myocyte by translocation of insulin-sensitive glucose (GLUT4) transporters to the cell membrane $[9,10]$. Similarly, during ischaemia when oxygen and nutrient supply are restricted, there is a shift towards glucose metabolism [9]. This occurs through a poorly understood pathway that ensures the most efficient (rather than the most abundant) substrate is utilised, as cell preservation becomes more important than maintaining contractile function. Energy transfer cycles break and become more linear with anaerobic metabolism of limited glycogen stores. There is an increase in intracellular calcium, reduction in $\mathrm{pH}$ and accumulation of metabolic waste products [5,7]. Without rapid restoration of perfusion, these events combine to activate intracellular signalling cascades, ultimately activating the processes of cell death by apoptosis and necrosis, contributing to infarction (Figure 1a). Necrosis predominates during ischaemia if accumulation of metabolic waste and calcium is sufficient to induce osmotic swelling. At reperfusion, necrosis may become accelerated, and, if cell death signals are activated, apoptosis ensues. The result of either is an area of infarcted tissue [11].

\section{Intracellular pathways of cardioprotection Metabolic pathway}

Manipulation of the heart's cellular energy metabolism to overcome the metabolic changes during ischaemia is an established concept in cardioprotection, as discussed above. Infusion of glucose-insulin-potassium (GIK) has been used to increase myocardial glucose uptake and glycolysis (and suppress fatty acid oxidation) protect against IRI. In preclinical studies, GIK has been protective, although transition to clinical practice has been limited. A number of studies in humans have produced variable results, potentially influenced by inconsistencies in factors such as dosage, metabolic status, glucose level and timing of administration [12]. The 'IMMEDIATE' study evaluated 12 hour IV GIK infusion initiated as soon as possible after the diagnosis of a possible acute coronary syndrome (ACS) before patients had been admitted to hospital. The study did not demonstrate an effect on progression of unstable angina to ACS, or 30-day mortality. There was, however, a significant reduction in the composite endpoint of cardiac arrest or in-hospital mortality, and limited imaging data showed a reduction in infarct size indicating a degree of cardioprotection [13]. The lack of definitive evidence combined with the practicalities and demands of administering insulin therapy safely have mitigated widespread adoption in clinical practice.

\section{Conditioning and the pro-survival kinase pathway}

Conditioning was first investigated in animals in the 1980s [14,15], and remote ischaemic preconditioning has recently been demonstrated to provide both short and long term MACE free survival benefit in humans [16]. Whilst remote ischaemic preconditioning and postconditioning have been proven effective, the mechanics and difficulty in predicting when lethal ischaemia will occur has prevented uptake in clinical practice [17].

The mechanisms of cardioprotection against IRI by conditioning have now been well established, even though the precise mechanism of activation remains unknown $[4,18,19]$. Derek Yellon and colleagues first described the reperfusion injury survival kinase (RISK) and survivor activating factor enhancement (SAFE) pro-survival kinase pathways and their pivotal role in the protective effects of preconditioning and postconditioning [20-22]. They involve activation of pro-survival kinases (reviewed here [23]) including phosphatidyl inositol 3 kinase (PI3K), protein kinase C (PKC), p38 mitogen-activated kinase (p38MAPK) and glycogen synthase kinase 3 beta (GSK $3 \beta$ ), forming a signalling cascade, converging on the mitochondria to reduce open probability of the mitochondrial permeability transition pore (mPTP) [24]. Preclinical studies support this idea, demonstrating that preventing opening of mPTP is a key step in conditioning mediated cardioprotection 
[25-27]. Pharmacological activation of the conditioning pathways offers promise for the future, overcoming the practical limitations of physical activation as a means of protecting against acute ischaemia-reperfusion injury $[27,28]$.

\section{Mitochondrial permeability transition pore (MPTP): a key step in conditioning pathways}

The mPTP is a non-selective pore located on the inner membrane of the mitochondria and, in it's normal closed state, preserves the membrane potential and $\mathrm{pH}$ gradient required for the oxidative production of ATP [29]. Opening of $\mathrm{MPTP}$ in response to the changes in the intracellular environment during ischaemia-reperfusion is detrimental to the mitochondria and is thought to be one of the mediators of IRI though initiation of cell death by necrosis or apoptosis [29], along with other damaging effects such as calcium overload. Factors that promote opening of the $\mathrm{MPTP}$ in ischaemia-reperfusion include increased intracellular calcium, $\mathrm{pH}$ gradient, oxidative stress and depletion of intracellular ATP [29-31]. The reduction in intracellular $\mathrm{pH}$ during ischaemia is initially able to inhibit opening of mPTP, probably through competitive inhibition of the $\mathrm{Ca}^{2+}$ trigger site by protons although this has not been fully characterized [32].

During early reperfusion the $\mathrm{pH}$ rapidly returns to physiological levels, and this appears to be an important factor that results in opening of the MPTP at the time point of reperfusion with adverse effects on the cell. Mitochondria become uncoupled with hydrolysis rather than synthesis of ATP. Unrestrained, this will lead to the loss of ionic homeostasis and eventually necrotic cell death. Preventing this process can contribute to the efficacy of a putative cardioprotective therapy to prevent IRI, and highlights that it should ideally be administered before reperfusion $[33,34]$.

\section{Cardioprotection through preventing opening of the MPTP} A number of animal models have confirmed that preventing $\mathrm{MPTP}$ opening can protect against IRI, with a reduction in oxidative stress and final infarct size [35]. In rabbits, this protected the heart against IRI by reducing apoptosis and necrosis both directly using a cyclosporine derivative to bind to cyclophillin-D (a component of $\mathrm{mPTP})$, and indirectly by pre-conditioning [36]. Clinically it would be important to promote an environment within the ischaemic myocyte that prevents opening of the MPTP on reperfusion [21,37-40]. A number of drugs are thought to influence opening of the MPTP, and some have been studied clinically to determine whether they can protect against IRI.

Direct interaction with the mPTP by cyclosporine modifies the calcium sensitive opening of the pore and thereby maintains closure during ischaemia [11,41]. Initial clinical studies of cyclosporine in those presenting with acute myocardial infarction in whom perfusion is restored by PCI have been promising, with significant reduction in infarct size measured by cardiac biomarkers troponin I and creatine kinase. A larger randomized clinical trial is currently ongoing $[42,43]$.

ATP-sensitive potassium $\left(\mathrm{K}_{\mathrm{ATP}}\right)$ channels are widely expressed, including on sarcolemma and mitochondrial membranes in cardiomyocytes [11]. The mitochondrial $\mathrm{K}_{\mathrm{ATP}}$ channel is believed to play a central role in conditioning mediated cardioprotection [44]. Alongside inhibiting mPTP opening, opening of $\mathrm{K}_{\mathrm{ATP}}$ is also important in protecting against IRI. It has long been appreciated that the sulphonylurea glibenclamide blocks $K_{\text {ATP }}$ channels in the heart [11] (in addition to its therapeutic effect achieved through inhibition of the channel in pancreatic beta cell, promoting insulin release).

\section{Potential use of GLP-1 as a cardioprotective agent}

GLP-1 is an incretin hormone, released from the L-cells of the small and large intestine in response to food intake. The intact form of the peptide, GLP-1 (7-36), has well-established metabolic actions, stimulating glucose dependent insulin release and suppressing glucagon to contribute to glucose homeostasis [45]. The metabolically active GLP-1 (7-36) is rapidly degraded by the enzyme dipeptidyl-peptidase-4 (DPP-4) to GLP-1 (9-36). Although inactive in the pancreas, it is thought that GLP-1 (9-36) may retain biological activity elsewhere, signaling either via the known GLP-1 G-protein-coupled receptor, or possibly a second unidentified receptor. Neutral endopeptidase (NEP) is also responsible for a significant proportion of GLP-1 degradation, acting at multiple cleavage sites [46], to form of further fragments including GLP-1 (28-36) and (32-36) that have been hypothesized to have potential activity at the mitochondria $[47,48]$. GLP-1 based therapies are now established as adjunctive treatment for type- 2 diabetes, with either oral DPP-4 inhibitors increasing endogenous GLP-1 (7-36), or DPP-4 resistant GLP-1 receptor agonists being given by subcutaneous injection [45]. The resulting glucose dependent insulin release and suppression of glucagon underlies the glycaemic efficacy of these agents. Data from small studies suggest that there is also potential for a beneficial effect on the heart during ischaemia through changes in the GLP-1 pathway, and this is illustrated in Figure 1b.

The choice of GLP-1 based therapy (administration of native GLP-1 (7-36), a GLP-1 receptor agonist, or a DPP-4 inhibitor) has important mechanistic considerations in terms of which elements of the GLP-1 axis are activated. Native GLP-1 (7-36) is not clinically available, but it is metabolized into the potentially active GLP-1 (9-36) and terminal fragments. While GLP-1 receptor agonists are now widely used, they are not metabolized 
to GLP-1 (9-36). DPP-4 inhibitors also prevent formation of GLP-1 (9-36), and have the potential to influence other DPP-4 substrates including stromal derived factor$1 \alpha($ SDF-1 $\alpha)$ (see Figure 2). A current theory is that a chronic increase in SDF- $1 \alpha$ may increase coronary collateralization, which is already known to improve LV diastolic dysfunction following coronary occlusion [49]. As we begin to understand which elements of the GLP-1 axis drive cardioprotection, the best approach can be identified.

\section{Possible mechanisms of cardioprotection with GLP-1}

GLP-1 has increased myocardial glucose uptake in dogs, which although carried out in dilated cardiomyopathy, still indicates it would increase myocardial oxygen efficiency and possibly drive the metabolic pathway of protection described previously [50]. The effect of GLP-1 on myocardial glucose uptake needs to be confirmed in humans. The RISK pathway can be initiated by pharmacological manipulation of numerous cell surface receptors including G-protein coupled receptors such as the known GLP-1 receptor [21]. Preclinical evidence demonstrates that GLP-1 can activate the pro-survival kinase pathways: in murine cardiomyocytes, GLP-1 was protective, stabilizing mitochondrial membrane potential and preventing activation of apoptosis via pro-survival kinases PI3K and ERK1/2 [51]. The involvement of the GLP-1 receptor in this activation remains unclear.
In the pancreas, GLP-1 receptor binding is known to transduce cAMP-PKA signaling [52,53], and this also takes place in the heart $[28,54]$. DPP-4 inhibition with sitagliptin increased cAMP and PKA activity, limiting infarct size in a mouse model [55]. Most recently, GLP-1 receptor mediated cAMP signaling was observed in cardiomyocytes with downstream signaling via exchange protein activated by cAMP-2 (ePAC2) [56]. This may contribute to cardioprotection directly or via modulation of the RISK pathway [57].

Preclinical studies have shown that GLP-1 is able to reduce final infarct size. For example, exendin-4 reduced infarct size with accompanying functional improvements in rats [58]. Lixisenatide also reduced infarct size within the area at risk by $36 \%$ in rats [59]. These findings support the theory that GLP-1 can protect myocytes against lethal IRI. The infarct limiting effects of sitagliptin, vildagliptin and GLP-1 (7-36) were recently shown to be glucose dependent for the first time [60], with protection lost at glucose levels below $5 \mathrm{mmol} / \mathrm{l}$. The suggestion that the myocardial benefits of GLP-1 might be differnet depending on the prevailing glucose concentration requires further investigation. Furthermore, the actual mechanism of benefit remains undefined and may include changes in both receptor and intracellular signaling. Recently it has been reported that high mobility group box 1 protein (HMGB1), a proposed mediator of the inflammatory response to tissue injury, may play a

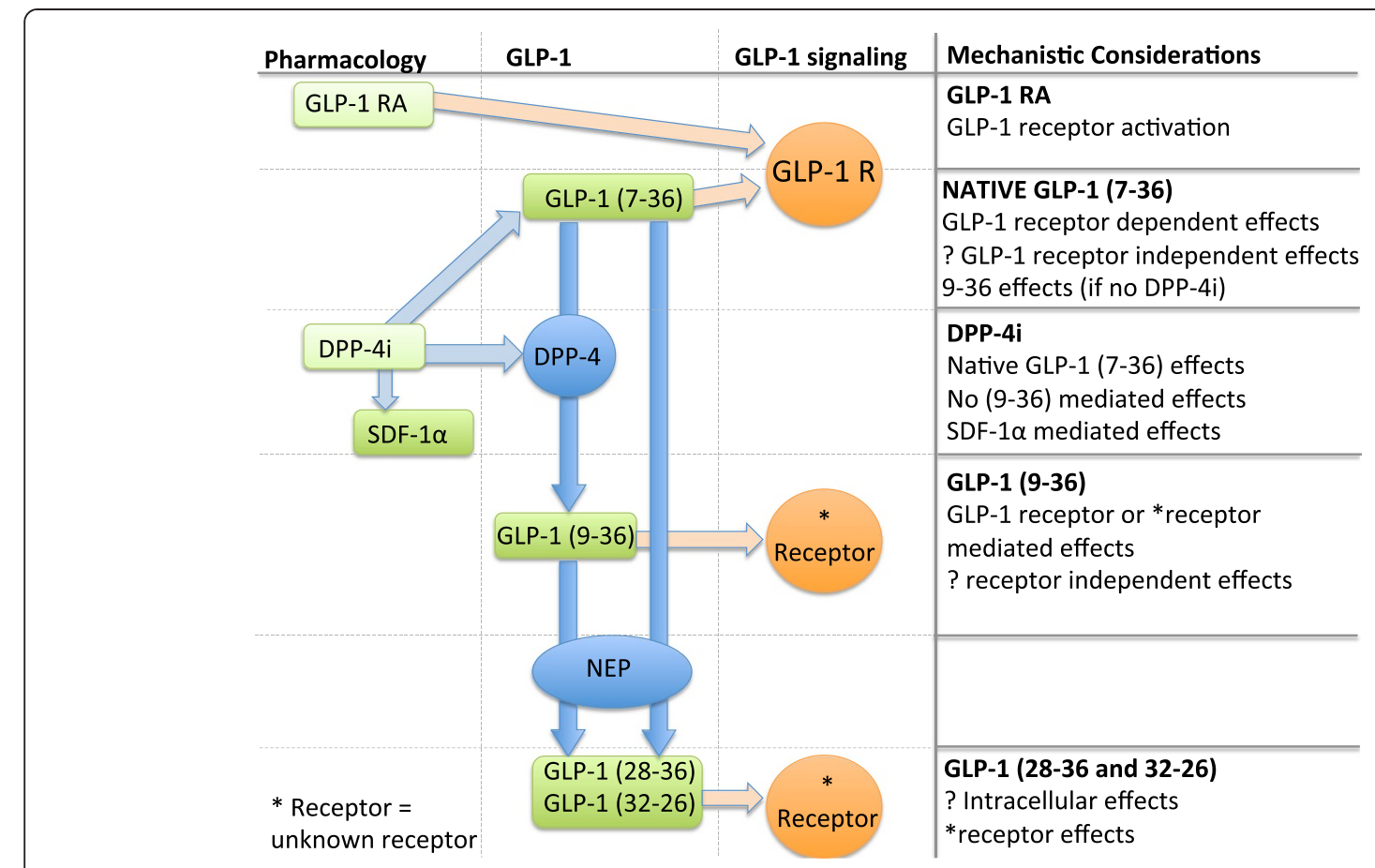

Figure 2 Illustrating the different therapeutic approaches targeting the GLP-1 axis and mechanistic considerations for each [46-48]. The possibilities of GLP-1 receptor independent effects and GLP-1 (28-36) and (32-36) mediated effects need validation. 
role in early IRI [61]. An interaction with the GLP-1 axis is supported by a study in anaesthatised rats where exendin-4 inhibited expression of HMGB1 accompanied by a reduction in infarct size [62].

\section{Location of the known GLP-1 receptor}

The location of the known G-protein coupled receptor for GLP-1 (7-36) remains controversial, and a consensus has not yet been reached. Early work by Ban et al. showed its expression throughout the cardiovascular system in mice where a protective effect of GLP-1 (7-36) was maintained in GLP-1 receptor knockout animals [63]. It is possible therefore, that GLP-1 might also provide cardioprotection via an unknown second receptor, a potential receptor independent mechanism, or by metabolic protection. A subsequent study in isolated mouse hearts showed that the GLP-1 receptor agonist Exendin4 conferred cardioprotection, and that GLP-1 (9-36) conferred protection to a lesser extent. The effect of GLP-1 (9-36) was again evident in GLP-1 receptor knockout mice, but was abolished by the GLP-1 receptor inverse agonist Exendin (9-39) [64], raising the possibility of a closely related second receptor. More recent work has indicated that GLP-1 receptors in the heart may be limited to only the atria and particularly the SA node, although this does not explain why improvements in LV performance and contractility are seen with GLP1 in various other experiments [56]. Some of the actions of GLP-1 could be mediated by terminal GLP-1 fragments such as GLP-1 (28-36) [48]. These findings support the possibility of GLP-1 receptor-independent effects, but should be considered preliminary until validated by further studies [56]. Data with a highly specific antibody and confirmation with mRNA sequencing is also needed to clarify where the GLP-1 receptor is located in the heart [65].

\section{Haemodynamic effects of GLP-1}

The potential haemodynamic effect of GLP-1 remains an area where consistent data is lacking. The question over the location of the GLP-1 receptor is central to this. Both GLP-1 (7-36) and (9-36) were vasodilators in mouse coronary arteries, at least in part via a receptor independent mechanism [63] and numerous other groups have identified a potential vasodilatory action of GLP-1 in animals [66-71]. Others have reported that GLP-1 and GLP-1 receptor agonists influence both heart rate and blood pressure in rats, potentially mediated both peripherally and centrally via the vagus nerve $[72,73]$.

Some preliminary human data supports the preclinical findings that GLP-1 is a vasodilator, but whether this contributes to cardioprotection remains to be seen. It has been suggested that GLP-1 receptor activation with exenatide could improve myocardial blood flow in humans [74].
GLP-1 has had beneficial effects on endothelial function in humans [75,76], and a study using a dose of $1.2 \mathrm{pmol} /$ $\mathrm{kg} / \mathrm{min}$ produced endothelium dependent vasodilation possibly involving nitric oxide and $\mathrm{K}_{\mathrm{ATP}}$ channels [77].

Heart rate increase is predictive of adverse cardiac morbidity and mortality and is therefore undesirable [78]. A meta-analysis found a small heart rate increase of 1.86 beats per minute with GLP-1 receptor agonists exenatide and liraglutide compared with placebo [79]. In a 26 week randomized controlled trial of liraglutide vs. sitagliptin, a dose dependent increase in heart rate from baseline (2.32 and 3.94 beats per minute for the $1.2 \mathrm{mg}$ and $1.8 \mathrm{mg}$ doses, respectively) was observed for liraglutide but not sitagliptin [80]. A single dose study found exenatide increased heart rate by 8.2 beats per minute compared with placebo accompanied by an increase in cardiac output and a reduction in total peripheral resistance [81]. So far, these observations have been limited to GLP-1 receptor agonists and a mechanism for heart rate increase is not known. Could an increase be mediated via GLP-1 receptor stimulation at the SA node, or via haemodynamic effects? Further work will help establish whether there is a clinically relevant effect.

\section{Evidence for acute GLP-1 mediated cardioprotection in humans}

Five studies reported by our own group have examined the effects of GLP-1 (7-36) infusion on myocardial response to ischaemia in humans. Using dobutamine stress echocardiography (DSE) as a model of demand ischaemia, we have demonstrated that an infusion of GLP-1 (7-36) elicited an improvement in cardiac performance compared to controls [82]. A similar cardioprotective effect was seen when the endogenous GLP-1 plasma concentration was increased with a single dose of the DPP-4 inhibitor sitagliptin. Myocardial performance at peak stress was improved and maintained to 30 minutes, and postischaemic stunning was abolished with sitagliptin [83]. More recently, we have reported initial findings from a follow up study, where GLP-1 (7-36) administered during DSE under hyperglycaemic conditions again improved tolerance to ischaemia and abolished postischaemic dysfunction [84]. We conducted a pilot study during elective PCI as a model of supply ischaemia, administering GLP-1 after the first balloon occlusion finding improvements in cardiac performance [85]. The GLP-1 infusion had the expected metabolic effects, increasing plasma insulin concentration with resultant plasma glucose and FFA concentration. Initial results from the follow up study have showed GLP-1 (7-36) administered before the first balloon occlusion protected against ischaemic LV dysfunction and attenuated stunning compared to controls [86]. Throughout this work we have observed increased tolerance of the myocardium to 
ischaemia with attenuation of post-ischaemic LV dysfunction (i.e. reduction in stunning) with GLP-1 (7-36). The effect appears apparent in those segments of myocardium subjected to ischaemia [82].

In a randomized, controlled trial of 172 patients presenting with ST-elevation MI, an infusion of exenatide administered prior to intervention reduced final infarct size (assessed by magnetic resonance imaging) with a $15 \%$ greater salvage index compared with placebo [87]. This is suggests that GLP-1 receptor agonism can protect against IRI, with reduction in infarct size supporting the hypothesis that fewer myocytes undergo apoptosis and necrosis. Unfortunately this apparent benefit was not associated with a reduction in peak plasma troponin concentration or by a demonstrable improvement in LV function measured at 90 days following MI. It is possible that cardiac MRI will overestimate AAR by detecting transient oedema in the myocardium. The LV function at 30 days was measured at rest. Resting LV function does not demonstrate the heart's ability to increase LV performance in response to increased demand, perhaps a more important measurement both in terms of clinical outcome and patient quality of life. An exercise or dobutamine stress test at 30 days may have been a better measure. It would be desirable to study this in future trials. Further work is also required to ascertain why exenatide apparently had no beneficial effect in patients with delayed reperfusion compared with a $30 \%$ reduction in final infarct size and $14 \%$ increase in myocardial salvage index in those where myocardial blood flow was restored promptly [87].

Our current understanding of the IRI pathways would seem to favour administration of GLP-1 before the point of reperfusion. However, two small studies in which GLP-1 was administered after reperfusion reported a beneficial effect. In addition to our own study described above, administration of a 72 hour GLP-1 (7-36) infusion after successful reperfusion following acute MI achieved both a global and regional improvement in LV function compared to control subjects [88].

These results are promising, and indicate that the protection against IRI observed in preclinical studies may also be present in humans. However, the mechanism by which GLP-1 offers protection to the ischaemic myocardium is not known. We suggest a pleiotropic mechanism, through a number of distinct, but inter-related, pathways: changes to the metabolic environment, insulin mediated effects, the pro-survival kinase pathways of cardioprotection, through cell surface receptor activation, or possibly even via receptor independent activity (Figure 1b) [18,22,23,89,90].

The common aspect of all these pathways is the ability to improve myocyte survival after an ischaemic insult, and therefore hopefully reduce the extent of infarction and preserve left ventricular (LV) function.
Various meta-analyses and pooled analyses of randomized controlled trials indicate that treatment with DPP-4 inhibitors or GLP-1 receptor agonists may reduce incidence of major adverse cardiovascular events, indicating a potentially beneficial effect of both approaches [91-95] While some of these meta-analyses indicate a lower rate of MACE events compared to comparator arms, and others indicate no difference, none of them are sufficient to decide whether or not there is a meaningful benefit. The first two prospective cardiovascular outcome studies of DPP-4 inhibitors have now reported, demonstrating no evidence of harm when used as a chronic treatment for type-2 diabetes $[96,97]$. The separate question of whether GLP-1 therapy can protect against acute IRI remains to be answered.

\section{Conclusions}

The advent of primary PCI has significantly improved outcome following MI, but there is still the potential to improve myocyte salvage and mitigate IRI to further improve clinical outcome. Increased understanding of the cellular processes underlying myocardial injury, and characterisation of intracellular signalling cascades associated with myocyte loss, has identified new potential therapies to beneficially target IRI.

Preclinical studies have shown GLP-1 has the potential to reduce IRI and improve functional parameters of recovery following significant myocardial ischaemia. Early human work supports this, although the location of the GLP-1 receptor and the precise mechanism of protection afforded by GLP-1 is not yet understood.

As GLP-1 based therapies are increasingly prescribed to patients with type- 2 diabetes, many of whom also have significant coronary artery disease, it will be important to continue careful surveillance to assess whether these patients are provided some degree of protection should they experience an ischaemic cardiac event. Further studies will help define whether GLP-1 is able to enhance cardiac outcome during an acute coronary syndrome, and add to understanding of the mode of action underlying any benefit.

\section{Limitations}

This work was not performed in accordance to the PRISMA guidelines for reporting systematic reviews [98].

\footnotetext{
Abbreviations

ACS: Acute coronary syndrome; DPP-4: Dipeptidyl-peptidase 4; DSE: Dobutamine stress echocardiography; ePAC2: Exchange protein activated by CAMP-2; FFA: Free fatty acid; GIK: Glucose-insulin-potassium; GLP-1: Glucagon-like peptide-1; GLUT4: Insulin sensitive glucose transporter 4; GSK 3ß: Glycogen synthase kinase 3 beta; IRI: Ischaemia reperfusion injury; $K_{\text {ATP: ATP-sensitive potassium }}$ channel; LV: Left ventricle; MI: Myocardial Infarction; MPTP: Mitochondrial permeability transition pore; NEP: Neutral endopeptidase; p38MAPK: p38 mitogen-activated kinase; PCl: Percutaneous coronary intervention; PI3K: Phosphatidyl inositol 3 kinase; PKC: Protein kinase C; RISK: Reperfusion injury survival kinase; SAFE: Survival activating factor enhancement.
} 


\section{Competing interests}

LMM and DPD declare that they have no competing interests. SJC recieves a salary from Merck Sharp and Dohme Ltd however this work was carried out independently.

\section{Authors' contributions}

SJC, LMM and DPD contributed equally to the preparation of this manuscript. All authors read and approved the final manuscript.

Received: 4 November 2013 Accepted: 4 January 2014

Published: 11 January 2014

\section{References}

1. Nagendran J, Oudit GY, Bakal JA, Light PE, Dyck JR, McAlister FA: Are users of sulfonylureas at the time of an acute coronary syndrome at risk of poorer outcomes? Diabetes Obes Metab 2013, 15:1022-1028.

2. Haffner SM, Lehto S, Ronnemaa T, Pyorala K, Laakso M: Mortality from coronary heart disease in subjects with type 2 diabetes and in nondiabetic subjects with and without prior myocardial infarction. N Engl J Med 1998, 339:229-234.

3. Frohlich GM, Meier P, White SK, Yellon DM, Hausenloy DJ: Myocardial reperfusion injury: looking beyond primary PCl. Eur Heart J 2013, 32(23):1714-1722.

4. Hausenloy DJ, Botker HE, Condorelli G, Ferdinandy P, Garcia-Dorado D, Heusch G, Lecour S, van Laake LW, Madonna R, Ruiz-Meana M, et al Translating cardioprotection for patient benefit: position paper from the working group of cellular biology of the heart of the european society of cardiology. Cardiovasc Res 2013, 98(1):7-27.

5. Hausenloy DJ, Yellon DM: Myocardial ischemia-reperfusion injury: a neglected therapeutic target. J Clin Invest 2013, 123:92-100.

6. Zhao ZQ, Corvera JS, Halkos ME, Kerendi F, Wang NP, Guyton RA, Vinten-Johansen J: Inhibition of myocardial injury by ischemic postconditioning during reperfusion: comparison with ischemic preconditioning. Am J Physiol Heart Circ Physiol 2003, 285:H579-H588.

7. Taegtmeyer H, King LM, Jones BE: Energy substrate metabolism, myocardial ischemia, and targets for pharmacotherapy. Am J Cardiol 1998, 82:54K-60K.

8. Page $E, M c C a l l i s t e r ~ L P:$ Quantitative electron microscopic description of heart muscle cells. Application to normal, hypertrophied and thyroxinstimulated hearts. Am J Cardiol 1973, 31:172-181.

9. Depre C, Vanoverschelde $J \amalg$, Taegtmeyer H: Glucose for the heart. Circulation 1999, 99:578-588.

10. Zaninetti D, Greco-Perotto R, Jeanrenaud B: Heart glucose transport and transporters in rat heart: regulation by insulin, workload and glucose. Diabetologia 1988, 31:108-113.

11. Ferdinandy P, Schulz R, Baxter GF: Interaction of cardiovascular risk factors with myocardial ischemia/reperfusion injury, preconditioning, and postconditioning. Pharmacol Rev 2007, 59:418-458.

12. Kloner RA, Nesto RW: Glucose-insulin-potassium for acute myocardial infarction: continuing controversy over cardioprotection. Circulation 2008, 117:2523-2533.

13. Selker HP, Beshansky JR, Sheehan PR, Massaro JM, Griffith JL, D'Agostino RB, Ruthazer R, Atkins JM, Sayah AJ, Levy MK, et al: Out-of-hospital administration of intravenous glucose-insulin-potassium in patients with suspected acute coronary syndromes: the IMMEDIATE randomized controlled trial. JAMA 2012, 307:1925-1933.

14. Murry $C E$, Jennings $R B$, Reimer KA: Preconditioning with ischemia: a delay of lethal cell injury in ischemic myocardium. Circulation 1986, 74:1124-1136

15. Reimer KA, Murry CE, Yamasawa I, Hill ML, Jennings RB: Four brief periods of myocardial ischemia cause no cumulative ATP loss or necrosis. Am J Physiol 1986, 251:H1306-H1315.

16. Davies WR, Brown AJ, Watson W, McCormick LM, West NE, Dutka DP, Hoole SP: Remote ischemic preconditioning improves outcome at 6 years after elective percutaneous coronary intervention: the CRISP stent trial longterm follow-up. Circ Cardiovasc Interv 2013, 6:246-251.

17. Hoole SP, Dutka DP: Does remote ischemic conditioning salvage left ventricular function after successful primary PCI? Expert Rev CardiovasC Ther 2011, 9:563-566.
18. Hausenloy DJ, Yellon DM: Preconditioning and postconditioning: underlying mechanisms and clinical application. Atherosclerosis 2009, 204:334-341.

19. Lehrke M, Marx N: Cardiovascular effects of incretin based therapies. Diabet Stud 2011, 8:382-391.

20. Schulman D, Latchman DS, Yellon DM: Urocortin protects the heart from reperfusion injury via upregulation of p42/p44 MAPK signaling pathway. Am J Physiol Heart Circ Physiol 2002, 283:H1481-H1488.

21. Hausenloy DJ, Lecour S, Yellon DM: Reperfusion injury salvage kinase and survivor activating factor enhancement prosurvival signaling pathways in ischemic postconditioning: two sides of the same coin. Antioxid Redox Signal 2011, 14:893-907.

22. Hausenloy DJ, Tsang A, Yellon DM: The reperfusion injury salvage kinase pathway: a common target for both ischemic preconditioning and postconditioning. Trends Cardiovasc Med 2005, 15:69-75.

23. Hausenloy DJ, Yellon DM: Survival kinases in ischemic preconditioning and postconditioning. Cardiovasc Res 2006, 70:240-253.

24. Hausenloy DJ, Ong SB, Yellon DM: The mitochondrial permeability transition pore as a target for preconditioning and postconditioning. Basic Res Cardiol 2009, 104:189-202

25. Javadov SA, Clarke S, Das M, Griffiths EJ, Lim KH, Halestrap AP: Ischaemic preconditioning inhibits opening of mitochondrial permeability transition pores in the reperfused rat heart. J Physiol 2003, 549:513-524.

26. Clarke SJ, Khaliulin I, Das M, Parker JE, Heesom KJ, Halestrap AP: Inhibition of mitochondrial permeability transition pore opening by ischemic preconditioning is probably mediated by reduction of oxidative stress rather than mitochondrial protein phosphorylation. Circ Res 2008, 102:1082-1090.

27. Okorie MI, Bhavsar DD, Ridout D, Charakida M, Deanfield JE, Loukogeorgakis SP, MacAllister RJ: Postconditioning protects against human endothelial ischaemia-reperfusion injury via subtype-specific KATP channel activation and is mimicked by inhibition of the mitochondrial permeability transition pore. Eur Heart J 2011, 32:1266-1274.

28. Bose AK, Mocanu MM, Carr RD, Brand CL, Yellon DM: Glucagon-like peptide 1 can directly protect the heart against ischemia/reperfusion injury. Diabetes 2005, 54:146-151.

29. Halestrap AP: Mitochondria and reperfusion injury of the heart-a holey death but not beyond salvation. J Bioenerg Biomembr 2009, 41:113-121.

30. Heusch G, Boengler K, Schulz R: Inhibition of mitochondrial permeability transition pore opening: the holy grail of cardioprotection. Basic Res Cardio/ 2010, 105:151-154.

31. Bernardi P, Broekemeier KM, Pfeiffer DR: Recent progress on regulation of the mitochondrial permeability transition pore; a cyclosporin-sensitive pore in the inner mitochondrial membrane. J Bioenerg Biomembr 1994 26:509-517

32. Halestrap AP: Calcium-dependent opening of a non-specific pore in the mitochondrial inner membrane is inhibited at $\mathrm{pH}$ values below 7 . Implications for the protective effect of low $\mathrm{pH}$ against chemical and hypoxic cell damage. Biochem J 1991, 278:715-719.

33. Griffiths EJ, Halestrap AP: Mitochondrial non-specific pores remain closed during cardiac ischaemia, but open upon reperfusion. Biochem J 1995, 307(Pt 1):93-98.

34. Halestrap AP: The mitochondrial permeability transition: its molecular mechanism and role in reperfusion injury. Biochem Soc Symp 1999, 66:181-203.

35. Hausenloy D, Duchen MR, Yellon DM: Inhibiting mitochondrial permeability transition pore opening at reperfusion protects against ischaemia-reperfusion injury. Cardiovasc Res 2003, 60:617-625.

36. Argaud L, Gateau-Roesch O, Muntean D, Chalabreysse L, Loufouat J, Robert D, Ovize M: Specific inhibition of the mitochondrial permeability transition prevents lethal reperfusion injury. J Mol Cell Cardio/ 2005, 38:367-374.

37. Hausenloy DJ, Yellon DM, Mani-Babu S, Duchen MR: Preconditioning protects by inhibiting the mitochondrial permeability transition. Am J Physiol Heart Circ Physiol 2004, 287:H841-H849.

38. Staat $P$, Rioufol G, Piot $C$, Cottin Y, Cung T, L'Huillier I, Aupetit JF, Bonnefoy E, Finet G, Andre-Fouet X, Ovize M: Postconditioning the human heart. Circulation 2005, 112:2143-2148.

39. Argaud L, Gateau-Roesch O, Raisky O, Loufouat J, Robert D, Ovize M: Postconditioning inhibits mitochondrial permeability transition. Circulation 2005, 111:194-197

40. Halestrap AP: A pore way to die: the role of mitochondria in reperfusion injury and cardioprotection. Biochem Soc Trans 2010, 38:841-860. 
41. Waldmeier PC, Feldtrauer JJ, Qian T, Lemasters JJ: Inhibition of the mitochondrial permeability transition by the nonimmunosuppressive cyclosporin derivative NIM811. Mol Pharmacol 2002, 62:22-29.

42. Ovize M: Cyclosporine and Prognosis in Acute Myocardial Infarction (MI) Patients (CIRCUS). In Book Cyclosporine and Prognosis in Acute Myocardial Infarction (MI) Patients (CIRCUS) (Editor ed.^eds.). City; 2013 http://clinicaltrials.gov/show/NCT01502774

43. Piot $C$, Croisille $P$, Staat $P$, Thibault $H$, Riofoul G, Mewton N, Elbelghiti R, Cung TT, Bonnefoy E, Angoulvant D, et al: Effect of cyclosporine on reperfusion injury in acute myocardial infarction.pdf. NEJM 2008, 359:473-481.

44. Garlid KD, Halestrap AP: The mitochondrial K(ATP) channel-fact or fiction? J Mol Cell Cardiol 2012, 52:578-583.

45. Ussher JR, Drucker DJ: Cardiovascular biology of the incretin system. Endocr Rev 2012, 33:187-215.

46. Plamboeck A, Holst JJ, Carr RD, Deacon CF: Neutral endopeptidase 24.11 and dipeptidyl peptidase IV are both mediators of the degradation of glucagon-like peptide 1 in the anaesthetised pig. Diabetologia 2005, 48:1882-1890.

47. Tomas E, Habener JF: Insulin-like actions of glucagon-like peptide-1: a dual receptor hypothesis. Trends Endocrinol Metab 2010, 21:59-67.

48. Mundil D, Beca S, Cameron-Vendrig A, El-Mounayri O, Momen A, Backx PH, Husain M: Abstract 13657: GLP-1 (28-36) exerts direct cardioprotective effects, activating Pro-survival kinases and soluble adenylyl cyclase. Circulation 2012, 126, A13657

49. Hoole SP, White PA, Read PA, Heck PM, West NE, O'Sullivan M, Dutka DP: Coronary collaterals provide a constant scaffold effect on the left ventricle and limit ischemic left ventricular dysfunction in humans. J Appl Physiol (1985) 2012, 112:1403-1409.

50. Nikolaidis LA, Elahi D, Hentosz T, Doverspike A, Huerbin R, Zourelias L, Stolarski C, Shen YT, Shannon RP: Recombinant glucagon-like peptideincreases myocardial glucose uptake and improves left ventricular performance in conscious dogs with pacing-induced dilated cardiomyopathy. Circulation 2004, 110:955-961.

51. Ravassa S, Zudaire A, Carr RD, Diez J: Antiapoptotic effects of GLP-1 in murine HL-1 cardiomyocytes. Am J Physiol Heart Circ Physiol 2011, 300:H1361-H1372.

52. Holst JJ: The physiology of glucagon-like peptide 1. Physio/ Rev 2007, 87:1409-1439.

53. Roed SN, Wismann $P$, Underwood CR, Kulahin N, Iversen $H$, Cappelen KA Schaffer L, Lehtonen J, Hecksher-Soerensen J, Secher A, et al: Real-time trafficking and signaling of the glucagon-like peptide- 1 receptor. $\mathrm{Mol}$ Cell Endocrinol 2013, 382(2):938-949.

54. Vila Petroff MG, Egan JM, Wang X, Sollott SJ: Glucagon-like peptide-1 increases CAMP but fails to augment contraction in adult rat cardiac myocytes. Circ Res 2001, 89:445-452.

55. Ye Y, Keyes KT, Zhang C, Perez-Polo JR, Lin Y, Birnbaum Y: The myocardial infarct size-limiting effect of sitagliptin is PKA-dependent, whereas the protective effect of pioglitazone is partially dependent on PKA. Am J Physiol Heart Circ Physiol 2010, 298:H1454-H1465.

56. Kim M, Platt MJ, Shibasaki T, Quaggin SE, Backx PH, Seino S, Simpson JA, Drucker DJ: GLP-1 receptor activation and Epac2 link atrial natriuretic peptide secretion to control of blood pressure. Nat Med 2013, 19:567-575.

57. Birnbaum Y, Castillo AC, Qian J, Ling S, Ye H, Perez-Polo JR, Bajaj M, Ye Y: Phosphodiesterase III inhibition increases CAMP levels and augments the infarct size limiting effect of a DPP-4 inhibitor in mice with type- 2 diabetes mellitus. Cardiovasc Drugs Ther 2012, 26:445-456.

58. Sonne DP, Engstrom T, Treiman M: Protective effects of GLP-1 analogues exendin-4 and GLP-1(9-36) amide against ischemia-reperfusion injury in rat heart. Regul Pept 2008, 146:243-249.

59. Wohlfart P, Linz W, Hubschle T, Linz D, Huber J, Hess S, Crowther D, Werner $U$, Ruetten $\mathrm{H}$ : Cardioprotective effects of lixisenatide in rat myocardial ischemia-reperfusion injury studies. J Trans/ Med 2013, 11:84

60. Hausenloy DJ, Whittington HJ, Wynne AM, Begum SS, Theodorou L, Riksen N, Mocanu MM, Yellon DM: Dipeptidyl peptidase-4 inhibitors and GLP-1 reduce myocardial infarct size in a glucose-dependent manner. Cardiovasc Diabetol 2013, 12:154.

61. Cai Y, Hu X, Yi B, Zhang T, Wen Z: Glucagon-like peptide-1 receptor agonist protects against hyperglycemia-induced cardiocytes injury by inhibiting high mobility group box 1 expression. Mol Biol Rep 2012, 39:10705-10711.
62. $H u$ G, Zhang $Y$, Jiang $H$, Hu X: Exendin-4 attenuates myocardial ischemia and reperfusion injury by inhibiting high mobility group box 1 protein expression. Cardiol J 2013, 20:600-604.

63. Ban K, Noyan-Ashraf MH, Hoefer J, Bolz SS, Drucker DJ, Husain M: Cardioprotective and vasodilatory actions of glucagon-like peptide 1 receptor are mediated through both glucagon-like peptide 1 receptordependent and -independent pathways. Circulation 2008, 117:2340-2350

64. Ban K, Kim KH, Cho CK, Sauve M, Diamandis EP, Backx PH, Drucker DJ, Husain M: Glucagon-like peptide (GLP)-1(9-36)amide-mediated cytoprotection is blocked by exendin(9-39) yet does not require the known GLP-1 receptor. Endocrinology 2010, 151:1520-1531.

65. Pyke C, Knudsen LB: The glucagon-like peptide-1 receptor-or not? Endocrinology 2013, 154:4-8.

66. Chai W, Dong Z, Wang N, Wang W, Tao L, Cao W, Liu Z: Glucagon-like peptide 1 recruits microvasculature and increases glucose use in muscle via a nitric oxide-dependent mechanism. Diabetes 2012, 61:888-896.

67. Golpon HA, Puechner A, Welte T, Wichert PV, Feddersen CO: Vasorelaxant effect of glucagon-like peptide-(7-36)amide and amylin on the pulmonary circulation of the rat. Regul Pept 2001, 102:81-86.

68. Green BD, Hand KV, Dougan JE, MCDonnell BM, Cassidy RS, Grieve DJ: GLP-1 and related peptides cause concentration-dependent relaxation of rat aorta through a pathway involving KATP and cAMP. Arch Biochem Biophys 2008, 478:136-142.

69. Richter G, Feddersen O, Wagner U, Barth P, Goke R, Goke B: GLP-1 stimulates secretion of macromolecules from airways and relaxes pulmonary artery. Am J Physiol 1993, 265:L374-L381.

70. Nystrom T, Gonon AT, Sjoholm A, Pernow J: Glucagon-like peptide-1 relaxes rat conduit arteries via an endothelium-independent mechanism. Regul Pept 2005, 125:173-177.

71. Ozyazgan S, Kutluata N, Afsar S, Ozdas SB, Akkan AG: Effect of glucagonlike peptide-1(7-36) and exendin- 4 on the vascular reactivity in streptozotocin/nicotinamide-induced diabetic rats. Pharmacology 2005, 74:119-126.

72. Gardiner SM, March JE, Kemp PA, Bennett T: Mesenteric vasoconstriction and hindquarters vasodilatation accompany the pressor actions of exendin-4 in conscious rats. J Pharmacol Exp Ther 2006, 316:852-859.

73. Barragan JM, Eng J, Rodriguez R, Blazquez E: Neural contribution to the effect of glucagon-like peptide-1-(7-36) amide on arterial blood pressure in rats. Am J Physiol 1999, 277:E784-E791.

74. Gejl M, Sondergaard HM, Stecher C, Bibby BM, Moller N, Botker HE, Hansen SB, Gjedde A, Rungby J, Brock B: Exenatide alters myocardial glucose transport and uptake depending on insulin resistance and increases myocardial blood flow in patients with type 2 diabetes. $J$ Clin Endocrinol Metab 2012, 97:E1165-E1169.

75. Nystrom T, Gutniak MK, Zhang Q, Zhang F, Holst JJ, Ahren B, Sjoholm A Effects of glucagon-like peptide- 1 on endothelial function in type 2 diabetes patients with stable coronary artery disease. Am J Physiol Endocrinol Metab 2004, 287:E1209-E1215.

76. Ceriello A, Esposito K, Testa R, Bonfigli AR, Marra M, Giugliano D: The possible protective role of glucagon-like peptide 1 on endothelium during the meal and evidence for an "endothelial resistance" to glucagon-like peptide 1 in diabetes. Diabetes Care 2011, 34:697-702.

77. Basu A, Charkoudian N, Schrage W, Rizza RA, Basu R, Joyner MJ: Beneficial effects of GLP-1 on endothelial function in humans: dampening by glyburide but not by glimepiride. Am J Physiol Endocrinol Metab 2007, 293:E1289-E1295.

78. Valensi P, Chiheb S, Fysekidis M: Insulin- and glucagon-like peptide-1induced changes in heart rate and vagosympathetic activity: why they matter. Diabetologia 2013, 56:1196-1200.

79. Robinson LE, Holt TA, Rees K, Randeva HS, O'Hare JP: Effects of exenatide and liraglutide on heart rate, blood pressure and body weight: systematic review and meta-analysis. BMJ Open 2013, 3:e001986. doi:10.1136/bmjopen-2012-001986.

80. Pratley RE, Nauck M, Bailey T, Montanya E, Cuddihy R, Filetti S, Thomsen AB, Sondergaard RE, Davies M, Group L-D-S: Liraglutide versus sitagliptin for patients with type 2 diabetes who did not have adequate glycaemic control with metformin: a 26-week, randomised, parallel-group, openlabel trial. Lancet 2010, 375:1447-1456.

81. Mendis B, Simpson E, MacDonald I, Mansell P: Investigation of the haemodynamic effects of exenatide in healthy male subjects. $\mathrm{Br} J \mathrm{Clin}$ Pharmacol 2012, 74:437-444. 
82. Read PA, Khan FZ, Dutka DP: Cardioprotection against ischaemia induced by dobutamine stress using glucagon-like peptide-1 in patients with coronary artery disease. Heart 2012, 98:408-413.

83. Read PA, Khan FZ, Heck PM, Hoole SP, Dutka DP: DPP-4 inhibition by sitagliptin improves the myocardial response to dobutamine stress and mitigates stunning in a pilot study of patients with coronary artery disease. Circ Cardiovasc Imaging 2010, 3:195-201.

84. McCormick LM, Kydd AC, Ring LS, Clarke SJ, Dutka DP: Glucagon-like peptide-1 improves the myocardial response to demand ischemia during hyperglycemia in patients with type 2 diabetes mellitus and coronary artery disease. Circulation 2013, 128:A17348.

85. Read PA, Hoole SP, White PA, Khan FZ, O'Sullivan M, West NE, Dutka DP: A pilot study to assess whether glucagon-like peptide-1 protects the heart from ischemic dysfunction and attenuates stunning after coronary balloon occlusion in humans. Circ Cardiovasc Interv 2011, 4:266-272

86. McCormick LM, Hoole SP, White PA, Read PA, Axell R, Clarke SJ, O'Sullivan M, West NEJ, Dutka DP: Pre-treatment with glucagon-like peptide-1 protects against supply ischemic left ventricular dysfunction - insights from conductance catheter assessment during elective $\mathrm{PCl}$. Circulation 2013, 128:A17497.

87. Lonborg J, Vejlstrup N, Kelbaek H, Botker HE, Kim WY, Mathiasen AB, Jorgensen E, Helqvist S, Saunamaki K, Clemmensen P, et al: Exenatide reduces reperfusion injury in patients with ST-segment elevation myocardial infarction. Eur Heart J 2012, 33:1491-1499.

88. Nikolaidis LA, Mankad S, Sokos GG, Miske G, Shah A, Elahi D, Shannon RP. Effects of glucagon-like peptide-1 in patients with acute myocardial infarction and left ventricular dysfunction after successful reperfusion. Circulation 2004, 109:962-965.

89. Hausenloy DJ, Yellon DM: Preconditioning and postconditioning: united at reperfusion. Pharmacol Ther 2007, 116:173-191.

90. Yellon DM, Hausenloy DJ: Realizing the clinical potential of ischemic preconditioning and postconditioning. Nat Clin Pract Cardiovasc Med 2005, 2:568-575.

91. Monami M, Ahren B, Dicembrini I, Mannucci E: Dipeptidyl peptidase-4 inhibitors and cardiovascular risk: a meta-analysis of randomized clinical trials. Diabetes Obes Metab 2013, 15:112-120.

92. Monami M, Dicembrini I, Martelli D, Mannucci E: Safety of dipeptidyl peptidase-4 inhibitors: a meta-analysis of randomized clinical trials. Curr Med Res Opin 2011, 27(Suppl 3):57-64

93. Engel SS, Golm GT, Shapiro D, Davies MJ, Kaufman KD, Goldstein BJ: Cardiovascular safety of sitagliptin in patients with type 2 diabetes mellitus: a pooled analysis. Cardiovasc Diabetol 2013, 12:3.

94. Johansen OE, Neubacher D, von Eynatten M, Patel S, Woerle HJ: Cardiovascular safety with linagliptin in patients with type 2 diabetes mellitus: a pre-specified, prospective, and adjudicated meta-analysis of a phase 3 programme. Cardiovasc Diabetol 2012, 11:3.

95. Best JH, Hoogwerf BJ, Herman WH, Pelletier EM, Smith DB, Wenten M, Hussein MA: Risk of cardiovascular disease events in patients with type 2 diabetes prescribed the glucagon-like peptide 1 (GLP-1) receptor agonist exenatide twice daily or other glucose-lowering therapies: a retrospective analysis of the LifeLink database. Diabetes Care 2011, 34:90-95.

96. Scirica BM, Bhatt DL, Braunwald E, Steg PG, Davidson J, Hirshberg B, Ohman $P$, Frederich R, Wiviott SD, Hoffman EB, et al: Saxagliptin and cardiovascular outcomes in patients with type 2 diabetes mellitus. $N$ Engl J Med 2013, 369:1317-1326.

97. White WB, Cannon CP, Heller SR, Nissen SE, Bergenstal RM, Bakris GL, Perez AT, Fleck PR, Mehta CR, Kupfer $S$, et al: Alogliptin after acute coronary syndrome in patients with type 2 diabetes. N Engl J Med 2013, 369:1327-1335.

98. Liberati A, Altman DG, Tetzlaff J, Mulrow C, Gotzsche PC, loannidis JP, Clarke M, Devereaux PJ, Kleijnen J, Moher D: The PRISMA statement for reporting systematic reviews and meta-analyses of studies that evaluate healthcare interventions: explanation and elaboration. BMJ 2009, 339:b2700.

doi:10.1186/1475-2840-13-12

Cite this article as: Clarke et al:: Optimising cardioprotection during myocardial ischaemia: targeting potential intracellular pathways with glucagon-like peptide-1. Cardiovascular Diabetology 2014 13:12.

\section{Submit your next manuscript to BioMed Central and take full advantage of:}

- Convenient online submission

- Thorough peer review

- No space constraints or color figure charges

- Immediate publication on acceptance

- Inclusion in PubMed, CAS, Scopus and Google Scholar

- Research which is freely available for redistribution

Submit your manuscript at www.biomedcentral.com/submit
( Biomed Central 